\title{
An unusual view of a pharyngeal pouch
}

\author{
Kiran Varadharajan, Deniz Hassan, Ashley Hay, Tunde Odutoye
}

Department of ENT,

St. George's Hospital, London, UK

\section{Correspondence to \\ Kiran Varadharajan, \\ kiranvarad@doctors.org.uk}

Accepted 19 November 2014

\section{DESCRIPTION}

An 86-year-old man presented to accident and emergency with symptoms and signs of a lower respiratory tract infection. He had a history of severe dysphagia and regurgitation of food associated with two-stone weight loss and a significant reduction in quality of life. The patient was well apart from recent coronary artery bypass graft surgery. He was treated successfully for aspiration pneumonia and a subsequent chest X-ray revealed a mediastinal fluid level consistent with a possible pharyngeal pouch (figure 1).

The patient was referred to the Ear, Nose and Throat clinic. Full examination of the head, neck and oral cavity (including flexible nasoendoscopy) revealed no abnormalities. A barium swallow confirmed a large pharyngeal pouch (figure 2). The patient went on to have successful endoscopic stapling of the pharyngeal pouch with an improvement in symptoms.

Pharyngeal pouches typically occur in patients aged over 70 years ${ }^{1}$ and can present with dysphagia, regurgitation, chest infections, aspiration, halitosis and loss of weight. ${ }^{1}{ }^{2}$ A barium swallow usually diagnoses a pharyngeal pouch. ${ }^{2}$ Pharyngeal pouches are managed with endoscopic stapling or open surgery. ${ }^{3}$

While a barium swallow test is the gold standard radiological investigation for a pharyngeal pouch, this unusual case illustrates the versatility of a plain chest radiograph in demonstrating a variety of pathology.

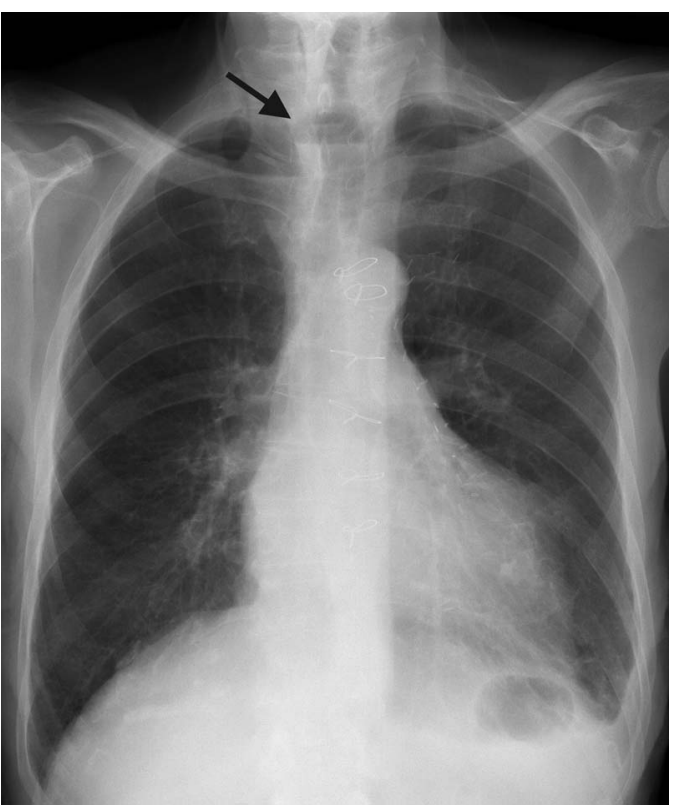

Figure 1 Plain chest X-ray demonstrating a mediastinal air-fluid level consistent with a pharyngeal pouch.

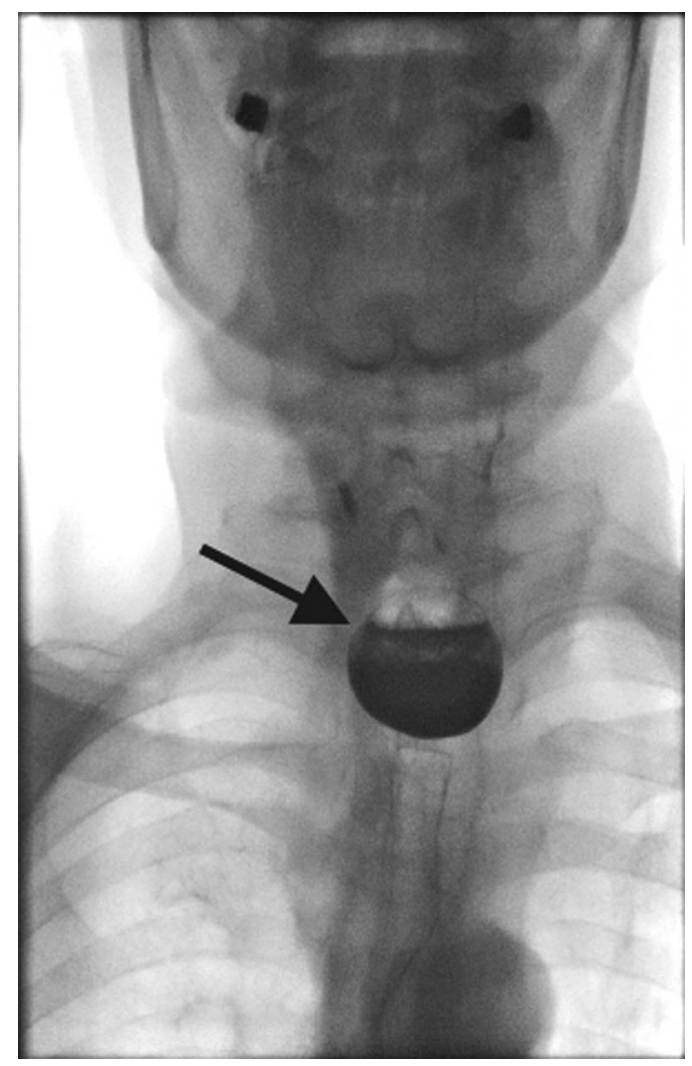

Figure 2 Barium swallow test revealing pharyngeal pouch.

\section{Learning points}

- A pharyngeal pouch is an important cause of dysphagia in older patients that can present with a variety of symptoms (including chest infections, weight loss and halitosis).

- The gold standard investigation for a pharyngeal pouch is a barium swallow test.

- This case demonstrates the versatility of a plain chest $\mathrm{X}$-ray in identifying a range of pathologies.

Competing interests None.

Patient consent Obtained.

Provenance and peer review Not commissioned; externally peer reviewed.

\section{REFERENCES}

1 Siddiq MA, Sood S, Strachan D. Pharyngeal pouch (Zenker's diverticulum). Postgrad Med J 2001;77:506-11.

2 Mirza S, Dutt SN, Minhas SS, et al. A retrospective review of pharyngeal pouch surgery in 56 patients. Ann R Coll Surg Engl 2002;84:247-51.

3 Sen P, Lowe DA, Farnan T. Surgical interventions for pharyngeal pouch. Cochrane Database Syst Rev 2005;(3):CD004459. 
Copyright 2014 BMJ Publishing Group. All rights reserved. For permission to reuse any of this content visit http://group.bmj.com/group/rights-licensing/permissions.

BMJ Case Report Fellows may re-use this article for personal use and teaching without any further permission.

Become a Fellow of BMJ Case Reports today and you can:

- Submit as many cases as you like

- Enjoy fast sympathetic peer review and rapid publication of accepted articles

- Access all the published articles

- Re-use any of the published material for personal use and teaching without further permission

For information on Institutional Fellowships contact consortiasales@bmjgroup.com

Visit casereports.bmj.com for more articles like this and to become a Fellow 